\title{
KURIKULUM PENDIDIKAN AGAMA ISLAM BERBASIS INTEGRASI PESANTREN-MADRASAH DI MTS NURUL UMMAH KOTAGEDE YOGYAKARTA
}

\author{
M Faishal Khoirurrijal \\ UIN Sunan Kalijaga Yogyakarta \\ Email: f41541_cb@outlook.com
}

\begin{abstract}
This research is motivated by the application of The Islamic Education curriculum based on the integration of pesantren-madrasah in MTs. Nurul Ummah Kotagede Yogyakarta. The purpose of this research was to find out the main factor of the application of The Islamic Religious Education curriculum based on the integration of Islamic Education curriculum based on the integration of pesantren-madrasah in MTs. Nurul Ummah and how the model is applied. The type of this research is descriptive qualitative which using three data collection methods; observation, interviews, and documentation. The results of this research showed that: 1) The main factor that resulted in the implementation of The Islamic Education curriculum was based on the integration of pesantren-madrasah in MTs. Nurul Ummah is due to the similarities between Islamic Education materials in MTs. Nurul Ummah with religious materials in the Nurul Ummah Islamic Boarding School for Students. 2) The model used in the Islamic Education curriculum is based on the integration of pesantren-madrasah in MTs. Nurul Ummah is within single diciplines, which is by combining the Diniyab subjects in the Nurul Ummah Islamic Boarding School for Students that have similarities with the Islamic Education subjects in MTs. Nurul Ummah which includes Al-Qur'an Hadis, Akidah Akhlak , Fikih, and Sejarah Kebudayaan Islam.
\end{abstract}

Keywords: Curriculum, Islamic Education, Integration.

\begin{abstract}
Abstrak
Penelitian ini dilatarbelakangi oleh adanya penerapan kurikulum Pendidikan Agama Islam berbasis integrasi pesantren-madrasah di MTs. Nurul Ummah Kotagede Yogyakarta. Tujuan penelitian ini untuk mengetahui latar belakang
\end{abstract}


diterapkannya kurikulum Pendidikan Agama Islam berbasis integrasi pesantren-madrasah di MTs. Nurul Ummah dan bagaimana model penerapannya. Jenis penelitian ini adalah deskriptif kualitatif yang menggunakan tiga metode pengumpulan data, yaitu observasi, wawancara, dan dokumentasi. Hasil penelitian menunjukkan bahwa: 1) Faktor utama yang melatarbelakangi diterapkannya kurikulum Pendidikan Agama Islam berbasis integrasi pesantren-madrasah di MTs. Nurul Ummah adalah karena adanya tumpang tindih antara pelajaran Pendidikan Agama Islam yang ada di MTs. Nurul Ummah dengan pelajaran keagamaan yang ada di Asrama Pelajar Pondok Pesantren Nurul Ummah. 2) Model yang digunakan dalam kurikulum Pendidikan Agama Islam berbasis integrasi pesantren-madrasah di MTs. Nurul Ummah adalah integrasi dalam satu bidang ilmu, yaitu dengan menggabungkan mata pelajaran Diniyah di Asrama yang memiliki kesamaan dengan mata pelajaran Pendidikan Agama Islam di MTs. Nurul Ummah yang meliputi Al-Qur'an Hadis, Akidah Akhlak, Fikih, dan Sejarah Kebudayaan Islam.

Kata Kunci: Kurikulum, Pendidikan Agama Islam, Integrasi.

\section{PENDAHULUAN}

Indonesia memiliki lembaga pendidikan khas yang disebut dengan pesantren, yaitu lembaga yang melestarikan dan mempertahankan pengajaran agama dengan materi-materi yang terperinci, di antaranya; tauhid, hadits, tafsir, bahasa Arab, akhlak, akidah, tasawuf, dan lain sebagainya. ${ }^{1}$ Rujukan atau buku yang digunakan sebagai sumber pembelajaran dalam pesantren adalah kitab-kitab ulama terdahulu yang mu'tabarah (kredibel). Pesantren diyakini sebagai produk pendidikan budaya Indonesia yang orisinil sekaligus menjadi lembaga pendidikan paling tua saat ini apabila disandingkan dengan lembaga pendidikan lain yang pernah ada di Indonesia. ${ }^{2}$ Lahir dari internal budaya bangsa Indonesia sendiri, pesantren kini menjadi salah satu lembaga pendidikan yang menasional dan sangat mudah ditemukan di berbagai penjuru Indonesia, meskipun dengan menyandang statusnya sebagai lembaga pendidikan non formal. Berdasarkan data EMIS tahun pelajaran 2018/2019, terdapat 21.921 lembaga pendidikan di indonesia yang

${ }_{1}^{1}$ Siti Maryam Munjiat, "Integrasi Kurikulum Pesantren Dan Madrasah Pada Pondok Pesantren Manba' ul 'Ulum Sindangmekar Dukupuntang Cirebon," Al-Tarbawi Al-Haditsah: Jurnal Pendidikan Islam 2, no. 2 (2 November 2017): hlm. 144, https://doi.org/10.24235/tarbawi.v2i2.2065.

${ }^{2}$ M Sulthon Masyhud dan Moh Khusnurdilo, Manajemen Pondok Pesantren, 2 ed. (Jakarta: Diva Pustaka, 2005), hlm. 1. 
berbentuk pesantren. ${ }^{3}$ Jumlah ini belum termasuk pesantren-pesantren yang belum terdata oleh Kemenag, karena masih banyak pesantren yang enggan untuk mendaftarkan lembaganya kepada Kemenag atau karena tidak cukupnya data yang dimiliki oleh pesantren tersebut.

Sejalan dengan kuantitasnya yang begitu banyak, pesantren juga memberikan sumbangsih yang besar dalam perjalanan bangsa ini. Banyak dari tokoh pejuang bangsa ini yang ditempa di pesantren. Mereka berjuang dengan totalitas tanpa adanya rasa takut. Mereka melakukan perlawanan fisik untuk mengusir bagsa penjahah, berkerjasama dengan para tokoh lainnya dalam upaya mendirikan bangsa, dan turut aktif untuk mempertahankan sekaligus mengisi era kemerdekaan dengan hal-hal posistif bersama-sama dengan komponen bangsa lainnya. Kiranya tidak dapat dikatakan berlebihan ketika pada rentang tahun 1959-1956, pesantren dianggap sebagai "alat revolusi" dan benteng keutuhan NKRI (Negara Kesatuan Republik Indonesia). Pada era ini dikenal beberapa tokoh nasional yang dibesarkan melalui pesantren, seperti KH Wahid Hasyim (salah satu anggota PPKI) dan KH Saifuddin Zuhri (Menteri Agama era Orde Lama). ${ }^{4}$ Selain ketiga tokoh tersebut, terdapat nama besar lain seperti KH Hasyim Asy'ari, Rais Akbar organisasi keagamaan Nahdlatul 'Ulama yang juga dinobatkan sebagai pahlawan nasional. Beliau terkenal dengan deklarasi resolusi jihad yang berisi tentang seruan kewajiban seluruh umat Islam untuk melawan penjajah Belanda saat agresi militer kedua dilakukan. Deklarasi resolusi jihad tersebut membakar dan mengobarkan semangat para santri untuk berjuang dan bertempur di jalan agama (jihad) sampai titik dara penghabisan untuk melawan kezaliman penjajah. Perjuangan tersebut berbuah manis dan berhasil mengusir para penjajah Belanda untuk tidak menginjakkan kaki mereka lagi di bumi pertiwi. Bahkan salah satu jendral pimpinan mereka pun tewas terbunuh dalam pertempuran tersebut, yaitu Brigadir Jenderal Aubertin Walter Sothern Mallaby. Kini, momen deklarasi resolusi jihad yang terjadi pada tanggal 22 Oktober 1945 tersebut secara resmi ditetapkan sebagai Hari Santri

\footnotetext{
${ }^{3}$ Ibnu Singorejo, "Jumlah Pondok Pesantren di Indonesia," diakses 15 Oktober 2019, https://pontren.com/2018/11/20/jumlah-pondok-pesantren-di-indonesia/.

${ }_{4}^{4}$ Amin Haedani dan Hanif Abdullah, Masa Depan Pesantren: Dalam Tantangan Modernitas dan Tantangan Kompleksitas Global (Jakarta: IRD Press, 2004), hlm. 11.
} 
Nasional oleh Presiden Joko Widodo melalui Keputusan Presiden Nomor 22 Tahun 2015.

Berpijak pada data dan fakta yang telah diuraikan di atas, dapat diketahui bahwa pondok pesantren merupakan lembaga pendidikan di Indonesia yang selain memiliki jumlah yang banyak, juga memiliki peran penting bagi bangsa ini, baik dalam bidang pendidikan maupun di luar bidang pendidikan. Pesantren dengan segala potensinya selalu berupaya untuk tetap eksis dan berkembang menyesuaikan dengan perubahan zaman yang ada. Sifat dinamis yang dimiliki oleh pesantren dalam menghadapi perubahan di dunia pendidikan di antaranya adalah karena diktum yang dipegangi oleh pesantren menghendaki demikian. Diktum tersebut yaitu al-muhafadhah 'ala alqodim al-sholeh wa alakhdzu bi al-jadid al-ashlah (menjaga dan melestarikan nilai-nilai terdahulu yang baik sekaligus mengambil nilai-nilai baru yang lebih baik).

Sudah lazim diketahui bahwa perubahan zaman saat ini terjadi begitu cepat, baik dalam bidang teknologi, ilmu pengetahuan, bahkan sampai pada pendidikan. Untuk mengahadapi perubahan tersebut, pesantren dengan statusnya sebagai salah satu lembaga pendidikan paling tua di Indonesia harus mampu untuk beradaptasi dengan baik. Di antara salah satu usaha pesantren untuk mengimbangi perubahan zaman terutama dalam bidang moderenisasi pendidikan adalah dengan mendirikan lembaga formal yang berbentuk madrasah, bahkan hingga sekolah umum.

Pesantren yang memiliki madrasah atau sekolah adalah pesantren yang memiliki pandangan atau prinsip yang lebih fleksibel. Dengan demikian, pesantren tersebut bisa bertahan lebih baik dibandingkan dengan pesantren yang tetap mempertahankan pendidikan tradisionalnya tanpa mencoba untuk memadukan dengan pendidikan modern dan enggan untuk memiliki madrasah atau sekolah. Dengan adanya pesantren, pendidikan tradisional yang fokus kepada tafaqquh fiddin (pendalaman dan penguatan agama) dapat tetap dijaga; dengan madrasah, kebijakan-kebijakan dari pemerintah terutama yang berkaitan dengan kurikulum - sekaligus tuntutan lingkungan dan masyarakat untuk mewujudkan anak-anak mereka menjadi insan yang memiliki budi pekerti luhur, paham ilmu agama 
dan menguasai ilmu pengetahuan umum, sains dan teknologi sekaligus bisa diakomodasi. ${ }^{5}$

Perbedaan yang paling mendasar antara pesantren dengan madrasah atau sekolah -selain status kelembagaan- terletak pada metodologi dan kurikulum pengajaran. Pesantren dengan ciri khas metodologi tradisional yang sederhana, sedangkan madrasah atau sekolah selalu berinovasi dengan metode modern yang dinamis. Meskipun demikian, bukan berarti kedua lembaga tersebut tidak dapat dipadukan atau diintegrasikan. Madrasah atau sekolah dapat diadaptasi oleh pesantren, atau sebaliknya, untuk dapat saling menyempurnakan dan menutupi kekurangan yang lain. Awalnya memang masing-masing lembaga pendidikan tersebut berjalan sendiri-sendiri tanpa adanya keterkaitan. Pesantren berjalan terusmenerus dengan pendidikan tradisional, sementara madrasah atau sekolah juga berjalan melalui sistem pendidikan yang lebih modern. Kemudian seiring dengan perkembangan dunia pendidikan, kususnya pendidikan Islam dan inovasi di dalamnya, maka munculah pesantren, madrasah, atau sekolah yang berupaya menerapkan pendidikan yang integratif, baik dalam bentuk paradigma, sistem pendidikan, manajemen, kurikulum, atau pun secara keseluruhan sekaligus.

Munculnya gagasan integrasi dalam dunia pendidikan Islam setidaknya disebabkan oleh dua hal utama. Pertama, karena pada dasarnya sistem pendidikan akan selalu mengalami perubahan sesuai dengan hukum alam. ${ }^{6}$ Setiap sistem pendidikan akan berjalan baik pada masanya dan dapat menjadi tidak efektif pada masa setelahnya sehingga tidak sanggup lagi dalam memenuhi tuntutan kebutuhan lingkungan dan masyarakat yang semakin hari semakin berkembang dan kompleks. Sistem pendidikan formal (seperti sekolah dan madrasah) dengan sistem pendidikan non formal (seperti pesantren) yang awalnya dibeda-bedakan, pada perkembangannya dapat saja keduanya disatukan untuk menemukan satu konsep baru pendidikan

${ }^{5}$ Siti Maryam Munjiat, “Integrasi Kurikulum Pesantren Dan Madrasah Pada Pondok Pesantren Manba'ul 'Ulum Sindangmekar Dukupuntang Cirebon," hlm. 144.

${ }^{6}$ Kartini Kartono, Tinjauan Politik Mengenai Sistem Pendidikan Nasional Beberapa Kritik dan Sugesti (Jakarta: Pradnya Paramita, 1997), hlm. 47. 
sebagai solusi atas promblem pendidikan yang belum terselesaikan selama ini. ${ }^{7}$

Kedua, karena adanya kesadaran akan keutuhan dan kesatuan ilmu pengetahuan sehingga muncullah gagasan penyatuan dan pengintegrasian ilmu. Gagasan integrasi tersebut muncul dan dikembangkan oleh para pemikir pendidikan Islam. Hal yang mendasari munculnya ide integrasi keilmuan adalah karena adanya dualisme dan dikotomi ilmu pengetahuan antara ilmu agama dan ilmu umum yang pada akhirnya mengakibatkan dikotomik sistem pendidikan. ${ }^{8}$ Dampak paling buruk yang diakibatkan oleh adanya dikotomi ilmu pengetahuan di dunia Islam adalah mundurnya umat Islam itu sendiri. Umat Islam akan memfokuskan diri mereka kepada Ilmu agama semata dan mengabaikan ilmu umum karena dianggap kurang penting. Dengan demikian umat Islam akan semakin tertinggal dari dunia Barat yang semakin maju dalam bidang sains dan teknologi. Umat Islam hanya akan menjadi konsumen dan target pasar tanpa bisa melakukan inovasi ataupun perubahan. Hal ini tentu bertolak belakang dengan prinsip kehidupan yang diajarkan dalam Islam. Islam tidaklah agama yang hanya terfokus untuk mencapai kebahagiaan hidup di akhirat semata, tetapi juga memperhatikan kebahagiaan hidup di dunia. Kebahagiaan akhirat dapat diraih dengan ilmu agama, sedangkan kebahagian dunia dapat diraih dengan ilmu-ilmu umum, sains, dan teknologi. Selain itu, dalam dunia dakwah sekarang ini, umat Islam tidak bisa hanya mengandalkan pengetahuan agama semata, tetapi juga harus menguasai teknologi dan ilmu-ilmu sosial karena dakwah pada masa ini tidak seperti dakwah pada masa Nabi dulu. Sekarang umat Islam dituntut untuk berdakwah dan menyebarkan ajaran Islam melalui media-media yang sangat banyak dan beragam sehingga mereka harus selalu aktif, inovatif, dan mengikuti perkembangan zaman.

Bertolak dari gagasan integrasi yang telah dikemukakan oleh para pakar pendidikan, maka saat ini mulai banyak lembaga

7 Imam Taulabi, "Integrasi Sistem Pendidikan Pesantren dan Sekolah," Jurnal Pemikiran Keislaman 24, no. 2 (23 September 2015): hlm. 13, https://doi.org/10.33367/tribakti.v24i2.169.

${ }^{8}$ Istikomah, "Integrasi Ilmu Sebuah Konsep Pendidikan Islam Ideal," Jurnal Pemikiran Keislaman 28, no. 2 (21 Desember 2017): hlm. 409, https://doi.org/10.33367/tribakti.v28i2.490. 
pendidikan Islam, baik yang berbentuk pesantren, madrasah, ataupun sekolah yang menerapkan integrasi dalam pendidikannya. Integrasi tersebut dianggap sebagai suatu terobosan hebat yang memiliki manfaat besar bagi kemajuan pendidikan Islam.

Di antara cara yang lazim ditempuh untuk menciptakan pendidikan yang integratif anatara pesantren dan madrasah atau sekolah adalah melalui integrasi kurikulum, yaitu dengan melebur kurikulum pesantren ke dalam kurikulum madrasah atau sekolah dan sebaliknya sehingga tidak ada sekat di antara keduanya. Salah satu madrasah yang berupaya untuk menerapkan kurikulum tersebut adalah MTs. Nurul Ummah Kotagede Yogyakarta dengan mengintegrasikan kurikulumnya dengan kurikulum yang ada pada Asrama Pelajar Pondok Pesantren Nurul Ummah. Adapun yang menjadi fokus perhatian dalam integrasi kurikulum tersebut adalah kurikulum Pendidikan Agama Islam.

Secara struktural, Pondok Pesantren Nurul Ummah dan MTs Nurul Ummah berada di bawah naungan Yayasan Pendidikan Bina Putra. Pondok Pesantren Nurul Ummah sendiri memiliki asrama khusus yaitu Asrama Pelajar yang diperuntukkan untuk santri yang masih berstatus sebagai pelajar di sekolah formal. Pada awalnya, antara MTs Nurul Ummah dan Asrama Pelajar Nurul Ummah keduanya terpisah satu sama lain dan mempunyai kurikulum tersendiri tanpa adanya keterhubungan. Pada perekmbangannya dilakukanlah upaya untuk melakukan integrasi kurikulum pada tahun ajaran 2014/2015. Kebijakan yang saat ini diberlakukan adalah dengan menerapkan integrasi antara kurikulum yang ada pada pada MTs Nurul Ummah dengan kurikulum yang ada pada Asrama Pelajar Pondok Pesantren Nurul Ummah. Kebijakan Yayasan Bina Putra untuk menerapkan integrasi kurikulum pesantren dan madrasah sebagai terobosan dalam mensikapi dinamisasi pendidikan modern merupakan langkah yang baik dan terbilang belum begitu populer diterapkan di banyak madrasah yang berada dalam naungan pesantren. 
Sebenarnya penelitihan terdahulu tentang integrasi kurikulum sudah banyak ditemukan, seperti peneleitian (1) Asnawan ${ }^{9}$ dalam peneltiannya tentang integrasi pendidikan pada Pondok Pesantren Assunniyyah Kencong Jember, (2) Ade Putri Wulandari ${ }^{10}$ tentang integrasi kurikulum pesantren dalam Kurikulum 2013 di SMK AlMunawwir Krapyak, (3) Muhammad Rouf ${ }^{11}$ tentang manajemen integrasi kurikulum madrasah dan pesantren di MAN 1 Malang dan Madrasah Terpadu MAN 3 Malang, dan (4) Syuhada ${ }^{12}$ tentang integrasi sistem pendidikan pesantren dan pendidikan madrasah di Pondok Pesantren DDI Mangkoso Barru. Yang membedakan penelitian ini dengan penelitihan terdahulu adalah fokus pembahasan dan ruang lingkup objek tempat penelitian. Penelitian ini fokus membahas tentang intgerasi kurikulum mata pelajaran PAI pada sebuah lembaga pendidikan formal swasta yang berbentuk madrasah, yaitu MTs. Nurul Ummah.

Adapun alasan utama peneliti memilih MTs. Nurul Ummah sebagai obyek penelitian adalah karena dua hal. Yang pertama yaitu karena MTs. Nurul Ummah merupakan madrasah swasta yang berada dalam lingkungan pesantren sehingga lebih mudah dan fleksibel dalam mengembangkan kurikulum pendidikannya. Kemudian yang kedua karena MTs. Nurul Ummah sudah beberapa tahun menerapkan kurikulum integratif tersebut, yaitu kurang lebih lima tahun sejak tahun pelajaran 2014/2015. Dalam jangka waktu lima tahun tersebut, maka dinamika kurikulum integratif pesantren dan madrasah di MTs. Nurul Ummah sudah melalui banyak pengembangan dan evaluasi.

Dari uraian latar belakang tersebut, maka peneliti mengadakan penelitian tentang kurikulum Pendidikan Agama Islam berbasis

${ }^{9}$ Asnawan, “Integrasi Pendidikan Formal dan Pendidikan Diniyah Salafiyah Terhadap Santri Assunniyyah Kencong Jember Sebagai Antisipasi Ouput Pesantren di Era Regulasi Pendidikan," Jurnal Falasifah 7, no. 1 (03 2016).

${ }_{10}$ Ade Putri Wulandari, "Integrasi Kurikulum Pesantren Dalam Kurikulum 2013 di SMK Al-Munawwir Krapyak Yogyakarta," Jurnal Al-Fahim 2, no. 1 (1 Maret 2020).

${ }^{11}$ Muhammad Rouf, "Manajemen Kurikulum Integratif Madrasah-Pesantren (Studi Multisitus di MAN 1 Malang dan Madrasah Terpadu MAN 3 Malang)" (Tesis, Malang, UIN Maulana Malik Ibrahim Malang, 2016).

${ }^{12}$ Syuhada, “Integrasi Sistem Pendidikan Pesantren dan Pendidikan Madrasah: Kasus di Pondok Pesantren DDI Mangkoso Barru" (Tesis, Makassar, UIN Alauddin Makassar, 2016). 
integrasi pesantren-madrasah di MTs Nurul Ummah. Adapun yang menjadi fokus pembahasan penelitian ini adalah tentang latarbelakang diterapkan kurikulum PAI berbasis integrasi pesantren-madrasah di MTs Nurul Ummah dan bagaimana model penerapannya.

\section{METODE PENELITIAN}

Peneliti memilih jenis penelitian kualitatif yang bersifat deskriptif dalam penelitian ini. Penelitian deskriptif kualitatif ditujukan untuk memecahkan masalah yang ditemukan saat ini berdasarkan data-data di lapangan melalui proses analisis dan interpretasi. ${ }^{13}$ Penggunaan pendekatan kualitatif dalam penelitian ini dikarenakan data yang akan diamati adalah data kurikulum Pendidikan Agama Islam di MTs. Nurul Ummah yang meliputi mata pelajaran Fiqih, Aqidah Akhlaq, Al-Qur'an Hadits, dan Sejarah Kebudayaan Islam dengan berbasis pada integrasi pesantren dan madrasah.

Observasi, wawancara, dan dokumentasi adalah metode pengumpulan data yang digunakan peneliti pada penelitian ini. Peneliti melakukan observasi atau mengamati langsung proses pembelajaran PAI di MTs. Nurul Ummah. Kemudian peneliti melakukan wawancara kepada Waka Kurikulum, MTs. Nurul Ummah, guru PAI MTs. Nurul Ummah, dan Kelapa Asrama Pelajar Pondok Pesantren Nurul Ummah, dan terakhir peneliti melakukan dokumentasi untuk mendapatkan data-data kurikulum PAI berbasis integrasi pesantren-madrasah di MTs. Nurul Ummah.

Untuk menganalisa data, peneliti memakai teknik deskripsi analitik. Seluruh data yang telah dikumpulkan tidak dianalisis dengan rumusan statistika, tetapi data tersebut dianalisis dan diinterpretasi dalam bentuk deskripsi untuk memberikan kejelasan temuan sesuai dengan realita yang terjadi di lapangan. Proses analisis tersebut menghasilkan suatu gambaran tentang situasi dan kondisi yang diteliti dalam bentuk narasi. Agar analisis menghasilkan pemaparan yang logis dan mudah dipahami, maka uraian pemaparan harus menyeluruh dan sistematis. ${ }^{14}$ Jadi analisis ini membahas tentang

${ }^{13}$ Ronny Kountur, Metode Penelitian untuk Penulisan Skripsi dan Tesis (Jakarta: PPM, 2004), hlm. 53-54.

${ }^{14}$ Nana Sudjana dan Ibrahim, Penelitian dan Penilaian Pendidikan (Bandung: Sinar Baru, 1989), hlm. 197-198. 
kurikulum Pendidikan Agama Islam berbais integrasi pesantrenmadrasah pada MTs. Nurul Ummah.

\section{KERANGKA TEORI Integrasi Kurikulum}

Sebelum membahas tentang integrasi kurikulum, penulis akan menjelaskan terlebih dahulu apa arti dari integrasi dan kurikulum. Kemudian apa yang dimaksud dengan integrasi kurikulum.

Pertama, yang menjadi pokok pembahasan, yaitu kurikulum. Secara etimologis, kata kurikulum diambil dari bahasa Yunani, yaitu curre yang semula merupakan istilah dalam bidang olahraga yang bermakna jarak dari start hingga sampai finish yang harus ditempuh oleh para pelari. ${ }^{15}$ Adapun dalam ranah pendidikan, kurikulum sudah menjadi sebuah istilah baku yang lazim ada dalam kegiatan pembelajaran, meskipun dengan definisi yang sangat banyak dan beragam. Kurikulum memiliki urgensi yang sangat besar dalam proses pembelajaran sehingga kurikulum dianggap sebagai salah satu inti dari proses pembelajaran. Hal ini dikarenakan kurikulum menjadi bidang yang paling langsung berpengaruh terhadap hasil pembelajaran, berbeda halnya dengan manajemen pendidikan, dan bimbingan siswa,. ${ }^{16}$

Kurikulum didefinisikan sebagai "seperangkat rencana dan pengaturan mengenai isi dan beban pelajaran serta cara yang digunakan sebagai pedoman penyelenggaraan kegiatan belajar mengajar" berdasarkan Undang-Undang Sistem Pendidikan Nasional tahun 2003 pasal 1 ayat $1 .{ }^{17}$ Kurikulum sendiri memiliki empat komponen utama yang harus terpenuhi sehigga dapat disebut sebagai kurikulum yang ideal, yaitu tujuan, materi pembelajaran, strategi pembelajaran, dan evaluasi. Tujuan kurikulum berisi tentang standarstandar kompetensi yang hendak dicapai dari pembelajaran yang berlanmgsung atau dalam bahasa yang lebih sederhana tujuan kurikulum yaitu bagaimana output peserta didik yang akan

${ }^{15}$ Muhaimin, Pengembangan Kurikulum Pendidikan Agama Islam, v ed. (Jakarta: Raja Grafindo Persada, 2012), hlm. 1.

${ }^{16}$ Nana Syaodih Sukmadinata dan Erliana Syaodih, Kurikulum dan Pembelajaran Kompetensi (Bandung: Refika Aditama, 2012), hlm. 31.

17 Syaifuddin Sabda, Model Kurikulum Terpadu IPTEK \& IMTAQ (Jakarta: PT. Ciputat Press Group, 2006), hlm. 21. 
dihasilkan dari pembelajaran. Kemudian materi pembelajaran berisi tentang apa saja yang harus disampaikan oleh pendidik dan dipelajari oleh peserta didik. Adapun strategi pembelajaran yang berisi tentang bagaimana cara pendidik menyampaikan materi kepada peserta didik agar mudah untuk dipahami dan dimengerti. Terakhir yakni evaluasi yang merupakan suatu proses pemeriksaan terhadap keberhasilan kurikulum untuk mengetahui apakah sudah sesuai dengan tujuan dan sasarannya.

Kedua, yaitu integrasi. Kata integrasi sendiri merupakan serapan dari bahasa Inggris, yaitu integration yang memiliki arti pembauran hingga menjadi satu kesatuan yang utuh dan bulat. ${ }^{18}$ Dua hal yang sudah diintegrasikan akan nampak menjadi sebuah kesatuan yang saling berpadu dan bersinergi satu sama lain.

Ketiga, yaitu integrasi kurikulum. Dari penjelasan yang telah dipaparkan, dapat dipahami secara sederhana bahwa integrasi kurikulum merupakan suatu upaya peleburan atau pembauran materi-materi yang ada dalam kurikulum sehingga tidak terdapat sekat-sekat yang saling memisahkan. Adapun dalam kaitanya dengan integrasi kurikulum madrasah dan pesantren, maka dapat dipahami sebagai upaya untuk melebur dan menyatukan kurikulum yang terdapat dalam madrasah dengan kurikulum yang ada pada pesantren agar menjadi satu kesatuan yang utuh dan dapat bersinergi.

Terkait dengan model kurikulum integratif, Fogarty mengemukakan bahwa terdapat tiga jenis integrasi yang dapat ditempuh untuk menyusun kurikulum integratif, yaitu integrasi dalam satu bidang ilmu/mata pelajaran (within single diciplines), integrasi lintas disiplin ilmu (Accros Several Diciplines), integrasi dalam dan lintas diri peserta didik (Within and Across Learners). ${ }^{19}$

Menurut Udin Fakhrruddin dkk., terdapat tiga model pengintegrasian disiplin keilmuan yang dapat dipilih oleh pesantren yang berupaya untuk menerapkan pendidikan integratif dengan memasukkan pendidikan umum pada pendidikan pesantren atau sebaliknya. Pertama, model pengintegrasian ke dalam paket kurikulum, yaitu dengan memasukkan pelajaran umum ke dalam

18 John M. Echols dan Hassan Shadily, Kamus Inggris-Indonesia (Jakarta: Gramedia Pustaka Utama, 2007), hlm. 407.

${ }^{19}$ Robin Fogarty, Integrate the Curricula (Illinois: IRI/Skylight Publishing, 1991), hlm. 61-65. 
kurikulum pesantren atau sebaliknya tanpa perlu merubahnya. Kedua, model penamaan disiplin ilmu yang menunjukkan hubungan antara disiplin ilmu umum dan keislaman, seperti ekonomi Islam, politik Islam, sosiologi Islam, dan lain sebagainya. Model ini mengharuskan untuk memodifikasi disiplin ilmu tersebut dengan memasukkan prinsip dan nilai keislaman di dalamnya. Ketiga, model pengintegrasian ke dalam pengajaran disiplin ilmu. Model ini menuntut para pengajar untuk mampu mengintegrasikan antar disiplin ilmu pada saat pembelajaran. ${ }^{20}$

\section{Kurikulum PAI Madrasah dan Kurikulum Pesantren}

Pada bagian sebelumnya sudah dijelaskan apa yang dimaksud dengan kurikulum dan urgensi kurikulum dalam pembelajaran. Kemudian pada bagian ini akan dijelaskan lebih lanjut tentang kurikulum PAI Madrasah dengan kurikulum pesantren. Masingmasing dari madrasah dan pesantren memiliki kurikulumnya tersendiri yang jelas berbeda satu sama lain. Perbedaan ini tentu dikarenakan perbedaan filosofis dan status lembaga pendidikan yang ada pada keduanya. Madrasah sebagai lembaga pendidikan formal yang berada dalam naungan Kementrian Agama mempunyai kurikulum yang sudah ditetapkan dan ditentukan oleh Kementrian terkait yang juga bersinergi dengan Kementrian Pendidikan dan Kebudayaan. Dalam konteks saat ini, maka kurikulum yang berlaku adalah Kurikulum 2013.

Adapun Pesantren sebagai lembaga pendidikan non-formal cenderung memiliki kurikulum yang beragam karena tidak adanya peraturan yang mengikat terkait bentuk kurikulum yang harus diterapkan. Dalam hal ini pesantren lebih bebas, fleksibel dan variatif dalam menentukan arah tujuan pembelajaran. Namun kelemahan yang muncul adalah tidak adanya standar baku yang dijadikan patokan dalam mengembangkan pembelajaran di pesantren, sehingga kualitas pendidikan pesantren yang ada tidak merata, ada pesantren yang memiliki kualitas pendidikan yang sangat bagus dan ada yang sebaliknya. Dengan demikian dapat disimpulkan bahwa kurikulum

${ }^{20}$ Udi Fakhruddin, Ending Bahrudin, dan Endin Mujahidin, “Konsep Integrasi dalam Sistem Pembelajaran Mata Pelajaran Umum di Pesantren," Ta'dibuna: Jurnal Pendidikan Islam 7, no. 2 (31 Oktober 2018): hlm. 229, https://doi.org/10.32832/tadibuna.v7i2.1394. 
madrasah lebih bersifat baku dan terseragam, sedangkan kurikulum pesantren bersifat non-baku dan variatif.

Hal utama yang menjadi perbedaan antara kurikulum madrasah dan kurikulum pesantren, selain pada bentuk kurikulumnya, adalah terletak pada muatan materinya. Tentu dua kurikulum yang berbeda memiliki muatan atau materi yang berbeda pula. Untuk lebih jelasnya akan dipaparkan muatan materi dari masing-masing kurikulum secara umum sebagimana berikut:

1. Materi PAI Madrasah

Materi pelajaran PAI yang ada dalam Madrasah haruslah berdasarkan pada kurikulum yang berlaku saat ini, yaitu Kurikulum 2013. Dalam Surat Keputusan Menteri Agama (KMA) Republik Indonesia No 117 tahun 2014 tentang implementasi kurikulum 2013 di madrasah, dijelaskan tentag mata pelajaran PAI yang harus ada dalam Madrasah, yaitu meliputi: 1) Al-Qur'an Hadis, 2) Akidah-Akhlak, 3) Fikih, dan 4) Sejarah Kebudayaan Islam. Masing-masing mata pelajaran tersebut pada dasarnya saling terkait dan melengkapi.

a. Al-Qur'an-Hadis sebagai sumber utama ajaran Islam, dalam arti keduanya menjadi sumber akidah-akhlak, syari'ah/fikih yang meliputi ibadah dan muamalah, sehingga kajiannya tidak dapat dilepaskan dari setiap unsur tersebut.

b. Akidah adalah pondasi atau pokok ajaran agama. Akidah menjadi titik tolak bagi syari'ah/fikih (yang meliputi ibadah dan muamalah), dan akhlak, yakni sebagai konsekuensi dan manifestasi dari keimanan dan keyakinan hidup. Akhlak adalah aspek sikap hidup atau kepribadian hidup manusia, yang mengatur hubungannya dengan Allah swt. dan hubungannya dengan sesama manusia lainnya. Hal itu menjadi sikap hidup dan kepribadian hidup manusia dalam menjalankan sistem kehidupannya.

c. Fikih adalah seperangkat aturan atau sistem yang mengatur hubungan manusia dengan Sang Pencipta, Allah swt. (Hablun Minallah), sesama manusia (Hablun Minan-nas), dan dengan makhluk lainnya (Hablun - Ma'al-Ghairi).

d. Sejarah Kebudayaan Islam (SKI) adalah catatan tentang perkembangan perjalanan hidup umat Islam dari masa ke masa dalam berinteraksi dengan tuhan (beribadah), berinteraksi 
dengan sesama manusia (bermuamalah), berakhlak, dan berinovasi dalam mengembangkan sistem kehidupan atau menyebarkan ajaran Islam di berbagai penjuru dunia yang dilandasi oleh akidah. ${ }^{21}$

2. Materi Pelajaran Pesantren

Sebenarnya pembahasan kurikulum belum banyak dikenal di pesantren. Istilah yang lebih familiar dalam dunia pesantren untuk menyebut kurikulum adalah materi pelajaran, karena lebih familiar dan mudah dikenal di dunia pesantren. ${ }^{22}$ Materi utama yang disampaikan atau diajarkan di pesantren tidak bisa terlepas dari materi tentang keislaman dan ilmu keislaman.

Pada masa awal perkembangan pesantren, yaitu ketika pembelajaran atau pengajian masih dilaksanakan di surau (musholla) atau masjid, kurikulum yang dipakai masih dalam bentuk yang sangat sederhana, yaitu berupa pokok ajaran Islam yang fundamental yang terbagi dalam tiga pembagian, yaitu iman, Islam, dan ihsan atau doktrin, ritual, dan mistik. Setelah itu, ketika pembelajaran atau pengajian yang ada di surau atau masjid berubah dan berkembang menjadi pondok pesantren, maka hal ini berpengaruh terhadap perubahan materi pelajaran. Dari sebelumnya sekedar pengetahuan pokok ajaran Islam kemudian menjadi disiplin-disiplin ilmu tersendiri seperti ilmu nahwu-shorof (gramatikal bahasa Arab), tafsir, ilmu kalam, fiqih, hingga ilmu tasawuf. ${ }^{23}$

Apabila dilihat dari sudut pandang implementasinya, maka kurikulum pesantren dapat dibagi menjadi tiga bidang, yaitu:

a. Teknis; seperti Fiqh, Ilmu Tafsir, Ilmu Dirayah/Mustholah Hadits, Mawaris, Hisab, dan Ilmu Falaq.

b. Hafalan; seperti pelajaran Al-Qur'an, hadis dan nahwushorof (ilmu tata bahasa Arab).

${ }^{21}$ Kementrian Agama Republik Indonesia, “Keputusan Menteri Agama Republik Indonesia Nomor: 165 Tahun 2014 Tentang Kurikulum 2013 Mata Pelajaran Pendidikan Agama Islam dan Bahasa Arab pada Madrasah," 2014, hlm. 37, https://jdih.kemenag.go.id/list-regulation/detail/5o6aaNE3nJGHgWKHc5uwUA==.

${ }^{22}$ Mujamil Qomar, Pesantren: Dari Transformasi Metodologi Menuju Demokratisasi Institusi (Jakarta: Penerbit Erlangga, tt), hlm. 108.

${ }^{23}$ Qomar, hlm. 109. 
c. Ilmu yang bersifat membina religiusitas dan spiritualitas; seperti Aqidah, Akhlaq, dan Tasawuf. ${ }^{24}$

Kemudian secara lebih rinci, Kementrian Agama melalui Dirjen Pendidikan Islam memberikan paparan yang jelas tentang standar kurikulum pesantren yang umum diterapkan pada kebanyakan pesantren. Marhalah atau tingkatan yang ada dibagi menjadi empat, yaitu tingkat dasar, tingkat menengah, tingkat menengah atas, dan tingkat tinggi. Adapun bahan ajar yang digunakan dalam pendidikan pesantren adalah kitab-kitab klasik berbahasa Arab, seperti Al-Jawahir al-Kalamiyyah, Safinah alNajah, Sullam al-Taufiq, Al-Ajurumiyyah, Al-Amtsilah alTashrifiyyah, dan lain sebagainya disesuaikan dengan tingkatan yang berlaku. ${ }^{25}$

\section{HASIL PENELITIAN DAN PEMBAHASAN \\ Integrasi Kurikulum MTs. Nurul Ummah dengan Asrama Pelajar PP Nurul Ummah}

Madrasah Tsanawiyah Nurul Ummah merupakan sekolah yang berada di bawah naungan Yayasan Pendidikan Bina Putra, terletak di RT 27 RW 06, JI. Raden Ronggo KG II/982, Kelurahan Prenggan Kecamatan Kotagede, Kota Yogyakarta Provinsi DI Yogyakarta. Madrasah ini berdiri di atas tanah seluas $1.178 \mathrm{~m}$ dengan berbagai bangunan pokok, yaitu ruang guru, ruang kelas, ruang TU (tata usaha), ruang laboratorium, ruang perpustakaan, ruang UKS (usaha kesehatan sekolah), ruang OSIS (organisasi siswa intra seklolah), ruangan BK (bimbingan dan konseling), dan halaman. ${ }^{26}$

Pada awal berdirinya, MTs. NU belum memiliki bangunan, dan sementara bergabung dengan Madrasah Aliyah Nurul Ummah (MANU). Seiring perjalanan waktu, Yayasan Pendidikan Bina Putra mampu mendirikan bangunan sendiri untuk MTs NU. Dan sampai

${ }^{24}$ Abdurrahman Mas'ud dkk., Dinamika Pesantren dan Madrasah (Yogyakarta: Pustaka Pelajar, 2002), hlm. 73.

25 Direktorat Jendral Kelembagaan Agama Islam Departemen Agama RI, Pondok Pesantren dan Madrasah Diniyah: Pertumbuhan dan Perkembangannya (Jakarta: Departemen Agama RI, 2003), hlm. 33.

${ }^{26}$ Akhmad Nasir, Wawancara Profil MTs Nurul Ummah, 2 November 2019. 
saat ini, MTs NU memiliki fasilitas bangunan sebagaimana yang telah disebutkan di atas. ${ }^{27}$

Madrasah Tsanawiyah Nurul Ummah - yang kemudian lebih dikenal dengan singkatan MTs NU Kotagede Yogyakarta - berdiri pada tanggal 1 Juli 2005. Madrasah ini adalah salah satu lembaga pendidikan formal yang secara kelembagaan berada di bawah naungan Yayasan Pendidikan Bina Putra Yogyakarta. Selain memiliki lembaga pendidikan formal, Yayasan Bina Putra juga memiliki lembaga pendidikan non formal berbentuk pesantren, yaitu Pondok Pesantren Nurul Ummah (PPNU) yang mana pesantren ini menjadi cikal bakal berdirinya lembaga-lembaga pendidikan lain, termasuk MTs Nurul Ummah. ${ }^{28}$

Pondok Pesantren Nurul Ummah (PP Nurul Ummah Kotagede) didirikan pada tahun 1986. Peletakkan batu pertama dilaksanakan oleh KH Asyhari Marzuqi dan KH Nawawi Ngrukem pada tanggal 9 Februari 1986, dan disaksikan oleh keluarga Krapyak. Adapun upacara peresmian dilaksanakan pada tanggal 11 Februari 1986, yaitu dua hari setelah peletakan batu pertama. Upacara tersebut dihadiri oleh Pengurus Wilayah Nahdlatul Ulama (PWNU) DIY, Bapak Sugiarto (Wali Kota Yogyakarta), dan masyarakat sekitar. Nama yang dipilih untuk pesantren tersebut adalah "Nurul Ummah" yang merupakan usulan dari H. Ahmad Arwan Bauis, S.H. dan kemudian disetujui dan ditetapkan melalui musyawarah bersama.

Diharapkan dengan digunakannya nama "Nurul Ummah" yang memiliki arti "Cahaya Umat", pesantren tersebut dapat menjadi lembaga pendidikan Islam untuk mempelajari dan menekuni ilmu agama (tafaqquh fiddin), dan dapat memancarkan cahaya pencerahan yang membimbing Umat dalam menggapai kehidupan bahagia dunia dan akhirat (al-sa'adah fi al-darayn). Untuk mendapatkan legal formal sebagai suatu lembaga pendidikan, Pondok Pesantren Nurul Ummah didaftarkan ke Departemen Agama Republik Indonesia dan memperoleh nomor piagam pondok pesantren dari Kantor Wilayah Departemen Agama Propinsi Daerah Istimewa Yogyakarta, yang ditandatangani oleh kepala bidang Pembinaan Perguruan Agama

${ }^{27}$ Nasir, Wawancara Profil MTs Nurul Ummah.

${ }^{28}$ Nasir. 
Islam; Drs. H. Abdur Rosyad dengan nomor A. 8655 tertanggal 06 Juli 1986. ${ }^{29}$

Pondok Pesantren Nurul Ummah memiliki Asrama pelajar (komplek E) yang merupakan asrama khusus yang disediakan bagi santri pondok pesantren Nurul Ummah yang masih berstatus pelajar MTs/SMP dan MA/SMA. Pada awalnya asrama pelajar bergabung dengan asrama mahasiswa. Akan tetapi dalam perjalannya banyak permasalahan yang muncul seperti sulitnya pengontrolan, banyak santri pelajar yang terpengaruh budaya merokok santri mahasiswa, suasana belajar yang kurang kondusif dan permasalahan lainya. Kemudian pada bulan Muharram 1424/Maret 2003 pengasuh pondok pesantren Nurul Ummah meresmikan asrama pelajar putra yang letaknya berdekatan dengan gedung MTs Nurul Ummah. Asrama yang dibangun di atas tanah seluas sekitar $831 \mathrm{~m} 2$ ini digunakan sebagai tempat kegiatan sekaligus menetap para santri pelajar, baik pelajar yang sekolah di Madrasah Aliyah Nurul Ummah, MTs Nurul Ummah maupun SMP/SMA favorit di Yogyakarta. ${ }^{30}$

Ada beberapa pesan penting yang disamapaikan oleh alMagfurlah KH. Asyhari Marzuqi terkait dengan keberadaan asrama pelajar ini. Diantaranya adalah bahwa keberadaan asrama ini bertujuan untuk menunjang kegiatan mengaji santri pelajar dan menunjang belajar santri agar prestasi di sekolahnya juga tetap baik. Selain itu al-Magfurlah K.H. Asyhari Marzuqi juga berpesan bahwa mengaji, salat berjama'ah dan sekolah merupakan ruh asrama pelajar komplek E ini. ${ }^{31}$

Pada awalnya pendiriannya MTs NU dan Asrama Pelajar Pondok Pesantren Nurul Ummah memiliki kurikulumnya sendirisendiri dan tidak terhubung secara langsung. MTs NU sebagai lembaga pendidikan formal fokus untuk menyelenggarakan pendidikan berdasarkan instruksi dan kebijakan-kebijakan pemerintah melalui Kementrian Agama, sedangkan Asrama Pelajar PP

${ }^{29}$ Tim Admisi Nurul Ummah, "Sejarah Singkat Pondok Pesantren Nurul Ummah," Official Website Yayasan Pendidikan Bina Putra, diakses 20 November 2019, https://nurulummah.com/beranda/.

${ }^{30}$ Ahmad Choirul Umam, Wawancara Profil Asrama Pelajar Nurul Ummah, 1 November 2019.

${ }^{31}$ Umam. 
Nurul Ummah fokus untuk menyelenggarakan pendidikan Islam yang berlandaskan kepada warisan ulama-ulama terdahulu.

Kemudian pada awal tahun pelajaran 2014/2015 diterapkanlah program baru yang disebut dengan integrasi kurikulum. Program baru ini berdampak kepada penerapan sistem pembelajaran full day school. MTs NU mewajibkan siswa tinggal di asrama (boarding school). Untuk siswa yang tinggal dengan orang tua dan jarak tempuh dari rumah sampai ke madrasah tidak lebih dari 8 kilometer diperbolehkan untuk laju. Kegiatan siswa-siswi dalam full day school dari pukul 06.50 WIB sampai pada pukul 15.00 WIB dan dilanjutkan dengan kegiatan ekstrakurikuler. ${ }^{32}$

Penerapan program baru ini tentu bukan tanpa alasan. Ada beberapa faktor utama yang mendasari diterapkannya program ini. Berikut adalah faktor-faktor utama tersebut;

a. Kesadaran bahwa pesantren dan madrasah merupakan satu kesatuan yang harus saling bersinergi.

b. Adanya tumpang tindih antara pembelajaran di sekolah dan pembelajaran di madrasah diniyah.

c. Beban belajar siswa terlalu banyak dan berat.

d. Adanya kecenderungan siswa untuk lebih memprioritaskan sekolah dari pada madrasah.

e. Adanya jarak dan kesenjangan antara pengelolah Madrasah dan pengelolah Asrama sehingga tidak ada koordinasi yang baik. $^{33}$

Dengan adanya kelima faktor utama tersebut, maka integrasi kurikulum menjadi hal yang sagat mendesak untuk diterapkan demi terwujudnya pembelajaran yang semakin efektif dan maksimal baik pada madrasah atau pada pesantren.

\section{Kurikulum PAl Berbasis Integrasi Pesantren-Madrasah di MTs. Nurul Ummah}

Adanya program baru berupa integrasi kurikulum MTs. Nurul Ummah dan Asrama Pelajar Pondok Pesantren Nurul Ummah yang diterapkan pada awal tahun pelajaran 2014/2015 berdampak secara

32 Umam.

${ }^{33}$ Akhmad Nasir, Wawancara Kurikulum MTs Nurul Ummah, 2 November 2019. 
langsung kepada perubahan kurikulum Pendidikan Agama Islam yang ada pada MTs. Nurul Ummah. Setelah diterapkannya integrasi kurikulum, MTs. Nurul Ummah berupaya untuk mengembangkan kurikulum PAI berbasis integrasi pesantren-madrasah.

Adapun faktor utama diterapkannya kurikulum PAI berbasis integrasi pesantren-madrasah di MTs. Nurul Ummah adalah karena terjadinya tumpang tindih antara pelajaran Pendidikan Agama Islam yang ada di MTs. Nurul Ummah dengan pelajaran keagamaan yang ada di Asrama Pelajar Pondok Pesantren Nurul Ummah. Hal ini terjadi karena masing-masing dari MTs. dan Asrama Pelajar mengajarkan materi pelajaran yang sama meskipun dengan menggunakan bahan ajar yang berbeda. Contohnya dalam pelajaran Akidah Akhlak di Madrasah ada pembahasan tentang sifat wajib bagi Allah yang mana pembahasan ini juga ditemukan dalam kitab Aqidatul Awam yang dikaji di Asrama. Contoh lain dalam pelajaran fikih di Madrasah terdapat pembahasan tentang shalat yang mana pembahasan ini juga dikaji di Asrama dengan menggunakan kitab Fathul Qorib. Adanya pembahasan yang sama tersebut mengakibatkan adanya tumpang tindih antara satu pelajaran dengan pelajaran lain dengan menghabiskan waktu pembelajaran yang banyak.

Hasil dari kurikulum PAI berbasis integrasi pesantren-madrasah di MTs. Nurul Ummah secara umum dapat dilihat dalam tabel di bawah ini:

Tabel 1: Hasil Integrasi Komponen Kurikulum

\begin{tabular}{|c|c|c|c|}
\hline Komponen & $\begin{array}{c}\text { Kurikulum } \\
\text { MTs. }\end{array}$ & $\begin{array}{c}\text { Kurikulum } \\
\text { Asrama }\end{array}$ & Hasil Integrasi \\
\hline Tujuan & $\begin{array}{l}\text { Meningkatkan } \\
\text { pemahaman, } \\
\text { keimanan, } \\
\text { penghayatan, } \\
\text { dan } \\
\text { pengalaman } \\
\text { santri terhadap } \\
\text { ajaran agama } \\
\text { Islam, sehingga } \\
\text { menjadi insan } \\
\text { muslim yang } \\
\text { bertakwa }\end{array}$ & $\begin{array}{l}\text { Mananamkan } \\
\text { pemahaman } \\
\text { dan } \\
\text { pengamalan } \\
\text { agama yang } \\
\text { menyeluruh } \\
\text { meliputi } \\
\text { akidah, syariat, } \\
\text { dan akhlak } \\
\text { yang } \\
\text { berlandaskan } \\
\text { terhadap Al- }\end{array}$ & $\begin{array}{l}\text { Menanamkan } \\
\text { sekaligus } \\
\text { meningkatkan } \\
\text { keimanan, } \\
\text { pemahaman, } \\
\text { penghayatan, } \\
\text { dan } \\
\text { pengalaman } \\
\text { siswa terhadap } \\
\text { ajaran Islam } \\
\text { yang } \\
\text { menyeluruh }\end{array}$ \\
\hline
\end{tabular}




\begin{tabular}{|c|c|c|c|}
\hline & $\begin{array}{l}\text { kepada Tuhan } \\
\text { YME, serta } \\
\text { memiliki akhlak } \\
\text { yang mulia } \\
\text { dalam } \\
\text { kehidupan } \\
\text { pribadi, } \\
\text { bermasyarakat, } \\
\text { berbangsa dan } \\
\text { bernegara. }\end{array}$ & $\begin{array}{l}\text { Qur'an dan } \\
\text { Hadis dengan } \\
\text { melalui } \\
\text { penafsiran dan } \\
\text { pemahaman } \\
\text { para ulama } \\
\text { terdahulu. }\end{array}$ & $\begin{array}{l}\text { meliputi } \\
\text { akidah, syariat, } \\
\text { dan akhlak, } \\
\text { yang } \\
\text { berlandaskan } \\
\text { kepada Al- } \\
\text { Qur'an dan } \\
\text { Hadis sesuai } \\
\text { dengan } \\
\text { pemahaman } \\
\text { para ulama } \\
\text { terdahulu, } \\
\text { agar siswa } \\
\text { menjadi } \\
\text { manusia } \\
\text { muslim yang } \\
\text { sempurna. }\end{array}$ \\
\hline Materi & $\begin{array}{c}\text { Buku Paket } \\
\text { Kemenag }\end{array}$ & $\begin{array}{c}\text { Kitab-kitab } \\
\text { klasik karya } \\
\text { ulama } \\
\text { terdahulu }\end{array}$ & $\begin{array}{c}\text { KI dan KD } \\
\text { mengambil } \\
\text { dari buku } \\
\text { paket } \\
\text { kemenag. } \\
\text { Sedangkan } \\
\text { materi diambil } \\
\text { dari kitab- } \\
\text { kitab } \\
\text { pesantren }\end{array}$ \\
\hline Strategi & $\begin{array}{c}\text { Ceramah, } \\
\text { diskusi, } \\
\text { demonstrasi, } \\
\text { resitasi }\end{array}$ & $\begin{array}{c}\text { Sorogan, } \\
\text { bandongan, } \\
\text { musyawarah }\end{array}$ & $\begin{array}{c}\text { Ceramah/ } \\
\text { bandongan, } \\
\text { diskusi/ } \\
\text { musyawarah, } \\
\text { demonstrasi, } \\
\text { resitasi, } \\
\text { sorogan }\end{array}$ \\
\hline Evaluasi & $\begin{array}{l}\text { Penilaian } \\
\text { Harian, } \\
\text { Penilaian } \\
\text { Tengah }\end{array}$ & $\begin{array}{l}\text { Penilaian } \\
\text { Harian, } \\
\text { Penilaian } \\
\text { Tengah }\end{array}$ & $\begin{array}{l}\text { Penilaian } \\
\text { Harian, } \\
\text { Penilaian } \\
\text { Tengah }\end{array}$ \\
\hline
\end{tabular}




\begin{tabular}{|l|c|c|c|}
\hline & Semester, & Semester, & Semester, \\
Penilaian Akhir & Penilaian Akhir & Penilaian \\
Semester & Semester & Akhir \\
& & & Semester \\
\hline
\end{tabular}

Adapun model yang digunakan dalam kurikulum PAI berbasis integrasi pesantren-madrasah MTs. Nurul Ummah adalah integrasi dalam satu disiplin ilmu, yaitu model organisasi kurikulum yang menggabungkan kompetensi beberapa mata pelajaran yang berada dalam satu disiplin keilmuan ke dalam satu mata pelajaran tersendiri. Dalam hal ini, MTs. Nurul Ummah berupaya untuk menggabungkan mata pelajaran Diniyah di Asrama yang memiliki kesamaan dengan mata pelajaran Pendidikan Agama Islam di MTs. yang meliputi AlQur'an Hadis, Akidah Akhlak, Fikih, dan Sejarah Kebudayaan Islam. Langkah yang ditempuh oleh MTs. Nurul Ummah dalam mengintegrasikan mata pelajaran PAI di Madrasah dengan mata pelajaran Diniyah di Asrama meliputi tiga hal, yaitu memadatkan waktu menjadi satu, memadukan bahan ajar, dan memadukan metode pembelajaran. ${ }^{34}$

Pertama, pemadatan waktu menjadi satu. Dengan adanya integrasi maka pembelajaran mata pelajaran yang memiliki keterkaitan dengan Pendidikan Agama Islam di Asrama ditiadakan dan digabungkan menjadi satu waktu di Madrasah Tsanawiyah. Dengan demikian waktu pembelajaran Diniyah di Asrama yang semula dilaksanakan di sore dan malam hari ditiadakan dan digabungkan ke dalam kegiatan belajar mengajar mata pelajaran Pendidikan Agama Islam pada pagi sampai siang hari di Madrasah Tsnawiyah. Dalam hal ini yang menjadi landasan dasar pemadatan waktu belajar adalah prinsip efisiensi. Efisiensi dalam kurikulum tercipta ketika usaha, biaya, waktu, dana, peralatan, dan tenaga yang digunakan dalam menuntaskan pembelajaran dapat terwujud secara optimal dan hasilnya juga maksimal. Dengan dipadatkannya pembelajaran Pendidikan Agama Islam menjadi satu waktu di Madrasah Tsanawiyah akan memperingan beban siswa dan mempermudah proses pembelajaran karena dilaksanakan dalam waktu yang lebih ringkas namun tetap dengan materi yang memadai.

${ }^{34}$ Nasir. 
Siswa tidak lagi menghabiskan banyak waktu untuk belajar materi Pendidikan Agama Islam pada pagi hari di madrasah dan belajar materi yang hampir serupa pada malam hari di madrasah diniyah pesantren. Alokasi waktu pembelajaran Pendidikan Agama Islam di MTs. Nurul Ummah masih mengacu kepada kurikulum yang ditetapkan oleh Kementrian Agama, yaitu 2 (dua) jam pelajaran setiap minggu per mata pelajaran PAI. Adapun rincian pelajaran yang dipadukan dan dipadatkan adalah sebagai berikut:

a. Al-Qur'an Hadis.

Mata pelajaran Diniyah di Asrama yang pembahasannya berkaitan dengan Al-Qur'an dan Hadis digabungkan menjadi satu ke dalam pelajaran Al-Qur'an Hadis di Madrasah. Mata Pelajaran tersebut adalah Tajwid, Tafsir, dan Hadis.

b. Akidah Akhlak

Mata pelajaran Diniyah di Asrama yang membahas tentang akidah dan akhlak digabungkan menjadi satu ke dalam pelajaran Akidah Akhlak di Madrasah. Mata pelajaran tersebut yaitu Tauhid dan Akhlak.

c. Fiqih

Mata pelajaran Diniyah di Asrama yang membahas tentang fikih, baik berupa fikih ibadah maupun muamalah digabungkan menjadi satu ke dalam pelajaran Fikih di Madrasah. Mata pelajaran tersebut hanya satu dan memiliki nama yang sama yaitu Fikih.

d. Sejarah Kebudayaan Islam

Khusus mata pelajaran Sejarah Kebudayaan Islam tidak dilakukan penggabungan sama sekali karena tidak terdapat mata pelajaran yang serupa dan sepadan dalam Diniyah.

Untuk lebih mudah dalam memahami penggabungan tersebut, maka riciannya disajikan dalam bentuk tabel sebagai berikut:

Tabel 2: Hasil Integrasi Mata Pelajaran

\begin{tabular}{|c|c|c|l|c|c|c|}
\hline \multirow{2}{*}{ No } & \multicolumn{2}{|c|}{$\begin{array}{c}\text { MTs. Nurul } \\
\text { Ummah }\end{array}$} & \multicolumn{2}{l|}{ PP Nurul Ummah } & \multicolumn{2}{|c|}{ Hasil Integrasi } \\
\cline { 2 - 7 } & Mapel & $\begin{array}{c}\text { Aloka } \\
\text { si }\end{array}$ & Mapel & $\begin{array}{c}\text { Aloka } \\
\text { si }\end{array}$ & Mapel & $\begin{array}{c}\text { Aloka } \\
\text { si }\end{array}$ \\
\hline 1 & Al- & $2 \mathrm{jp}$ & $\begin{array}{l}\bullet \text { Tajwid } \\
\text { Qur'an }\end{array}$ & $\begin{array}{c}1 \mathrm{jp} \\
1 \mathrm{jp}\end{array}$ & $\begin{array}{c}\text { Al-Qur'an } \\
\text { Hadis }\end{array}$ & $2 \mathrm{jp}$ \\
& & $\begin{array}{l}\text { - Tafsir } \\
\text { Hadis }\end{array}$ & Hadis & $1 \mathrm{jp}$ & & \\
\hline
\end{tabular}




\begin{tabular}{|c|c|c|c|c|c|c|}
\hline 2 & $\begin{array}{c}\text { Akidah } \\
\text { Akhlak }\end{array}$ & $2 \mathrm{jp}$ & $\begin{array}{l}\bullet \text { Tauhid } \\
\bullet \text { Akhlak }\end{array}$ & $\begin{array}{c}1 \mathrm{jp} \\
1 \mathrm{jp}\end{array}$ & $\begin{array}{c}\text { Akidah } \\
\text { Akhlak }\end{array}$ & $2 \mathrm{jp}$ \\
\hline 3 & Fikih & $2 \mathrm{jp}$ & $\bullet$ Fikih & $2 \mathrm{jp}$ & Fikih & $2 \mathrm{jp}$ \\
\hline 4 & SKI & $2 \mathrm{jp}$ & - & - & SKI & $2 \mathrm{jp}$ \\
\hline
\end{tabular}

Kedua, pemaduan bahan ajar. Dengan adanya integrasi, maka MTs. Nurul Ummah berupayah untuk memadukan bahan ajar mata pelajaran yang telah digabungkan. Cara yang ditempuh adalah dengan memadukan buku paket Pendidikan Agama Islam dari Kemenag sebagai pedoman utama dengan kitab-kitab yang diajarkan di Asrama sebagai pendukung dan penunjang. Ketika materi-materi pembelajaran PAI dalam buku paket ditemukan juga dalam kitabkitab yang dipelajari di Asrama, maka refrensi utama yang digunakan adalah kitab-kitab tersebut, namun dengan tetap mengacu kepada KI dan KD yang ada dalam buku paket. Sedangkan materi-materi yang sulit ditemukan dalam kitab, maka refrensi utamanya kembali kepada materi dalam buku paket. Prinsip pemaduan bahan ajar ini mengacu pada efektifitas. Dengan dipadukannya buku paket PAI dan kitabkitab klasik pesantren, siswa dapat memperoleh pembelajaran yang efektif. Di satu sisi, siswa dapat memperoleh pembelajaran yang sistematis melalui KI KD dan materi yang ada pada buku paket PAI dan di sisi lain, siswa dapat memperoleh materi dengan rujukanrujukan yang original dari kitab-kitab klasik khas pesantren. Adapun rincian pemaduan bahan ajar adalah sebagai berikut:

a. Al-Qur'an Hadis.

Bahan ajar yang dipadukan adalah buku paket Al-Qur'an Hadis dari Kemenag dengan kitab Syifa'ul Jinan, Tafsir Ibriz juz 30, dan kitab hadis Riyadhus Shalihin. Kitab Syifa'ul Jinan, Tafsir Ibriz juz 30 menjadi materi pembelajaran Al-Qur'an dan kitab Riyadhus Shalihin sebagai materi pembelajaran Hadis.

b. Akidah Akhlak

Bahan ajar yang dipadukan adalah buku paket Akidah Akhlak dari Kemenag dengan kitab Taisirul Kholaq, Aqidatul Awam, dan Jawahir Kalamiyah. Kitab Aqidatul Awam, dan Jawahir Kalamiyah menjadi materi pembelajaran Akidah dan kitab Taisirul Kholaq sebagai materi pembelajaran Akhlak. 
c. Fiqih

Bahan ajar yang dipadukan adalah buku paket Fikih dari Kemenag dengan kitab Durusul Fiqhiyah jilid 2 dan kitab Matan Ghayah wa Taqrib.

d. Sejarah Kebudayaan Islam

Khusus untuk pelajaran SKI, MTs. Nurul Ummah hanya menggunakan buku paket SKI dari Kemenag. Hal ini dikarenakan adanya kesulitan dalam menentukan kitab-kitab tarikh yang pembahasaanya relevan dengan KI dan KD yang ada dalam buku paket.

Untuk lebih mudahnya dapat dilihat pada tabel berikut:

Tabel 3: Hasil Integrasi Materi Pembelajaran

\begin{tabular}{|c|c|c|c|c|}
\hline No & $\begin{array}{c}\text { Mata } \\
\text { Pelajaran }\end{array}$ & $\begin{array}{c}\text { MTs. Nurul } \\
\text { Ummah }\end{array}$ & $\begin{array}{l}\text { PP Nurul } \\
\text { Ummah }\end{array}$ & Hasil Integrasi \\
\hline 1 & $\begin{array}{c}\text { Al- } \\
\text { Qur'an } \\
\text { Hadis }\end{array}$ & $\begin{array}{c}\text { Buku Paket } \\
\text { Al-Qur'an } \\
\text { Hadis } \\
\text { Kemenag }\end{array}$ & $\begin{array}{l}\text { - Syifa'ul Jinan } \\
\text { - Tafsir Ibriz } \\
\text { Juz } 30 \\
\text { - Riyadus } \\
\text { Sholihin }\end{array}$ & $\begin{array}{l}\text { Buku Paket Al- } \\
\text { Qur'an Hadis } \\
\text { Kemenag sebagai } \\
\text { acuan KI KD dan } \\
\text { kitab Syifa'ul } \\
\text { Jinan, Tafsir Ibriz } \\
\text { Juz 30, dan } \\
\text { Riyadus Sholihin } \\
\text { sebagai sumber } \\
\text { materi. }\end{array}$ \\
\hline 2 & $\begin{array}{l}\text { Akidah } \\
\text { Akhlak }\end{array}$ & $\begin{array}{c}\text { Buku Paket } \\
\text { Akidah } \\
\text { Akhlak } \\
\text { Kemenag }\end{array}$ & $\begin{array}{l}\text { - Taisirul } \\
\text { Kholaq } \\
\text { - Aqidatul } \\
\text { Awam } \\
\text { - Jawahir } \\
\text { Kalamiyah }\end{array}$ & $\begin{array}{l}\text { Buku Paket } \\
\text { Akidah Akhlak } \\
\text { Kemenag sebagai } \\
\text { acuan KI KD dan } \\
\text { kitab Taisirul } \\
\text { Kholaq, Aqidatul } \\
\text { Awam, dan } \\
\text { Jawahir Kalamiyah } \\
\text { sebagai sumber } \\
\text { materi. }\end{array}$ \\
\hline 3 & Fikih & $\begin{array}{c}\text { Buku Paket } \\
\text { Fikih } \\
\text { Kemenag }\end{array}$ & $\begin{array}{l}\text { - Durusul } \\
\text { Fiqhiyah jilid } \\
2 \\
\text { - Matan }\end{array}$ & $\begin{array}{l}\text { Buku Paket Fikih } \\
\text { Kemenag sebagai } \\
\text { acuan KI KD dan } \\
\text { kitab Durusul }\end{array}$ \\
\hline
\end{tabular}




\begin{tabular}{|c|c|c|c|l|}
\hline & & $\begin{array}{l}\text { Ghayah wa } \\
\text { Taqrib }\end{array}$ & $\begin{array}{l}\text { Fiqhiyah jilid 2 } \\
\text { serta Matan } \\
\text { Ghayah wa Taqrib }\end{array}$ \\
\hline 4 & SKI & $\begin{array}{c}\text { Buku Paket } \\
\text { SKI Kemenag }\end{array}$ & - & $\begin{array}{l}\text { Buku Paket SKI } \\
\text { Kemenag }\end{array}$ \\
\hline
\end{tabular}

Ketiga, pemaduan metode pembelajaran. Metode pembelajaran yang diterapkan dalam mata pelajaran Pendidikan Agama Islam di MTs. Nurul Ummah adalah dengan memadukan metode modern dan klasik. Metode modern yang dimaksud seperti active learning dan cooperative learning. Sedangkan metode klasik yang dimaksud adalah metode pembelajaran yang sudah berpuluh-puluh tahun diterapkan di pesantren seperti sorogan, bandongan, dan musyawarah. Dengan adanya pemaduan beberapa metode tersebut, maka setiap metode dapat melengkapi kekurangan metode yang lain karena pada hakikatnya tidak ada metode yang paling sempurna. Masing-masing metode mempunyai keunggulan dan kekurangan yang apabila dipadukan akan dapat menghasilkan proses pembelajaran yang maksimal. Dalam hal ini memang pendidik memiliki peranan penting dalam menentukan metode yang akan digunakan sesui dengan tujuan pembelajaran, karakteristik mata pelajaran dan kondisi siswa.

\section{KESIMPULAN}

Faktor utama diterapkannya kurikulum PAI berbasis integrasi pesantren-madrasah adalah terjadinya tumpang tindih antara pelajaran Pendidikan Agama Islam yang ada di MTs. Nurul Ummah dengan pelajaran keagamaan yang ada di Asrama Pelajar PP Nurul Ummah.

Model yang digunakan dalam kurikulum PAI berbasis integrasi pesantren-madrasah di MTs Nurul Ummah adalah model integrasi dalam satu disiplin ilmu, yaitu model organisasi kurikulum yang menggabungkan kompetensi beberapa mata pelajaran yang berada dalam satu disiplin keilmuan ke dalam satu mata pelajaran tersendiri. Dalam hal ini, MTs. Nurul Ummah berupaya untuk menggabungkan mata pelajaran Diniyah di Asrama yang memiliki kesamaan dengan mata pelajaran Pendidikan Agama Islam yang meliputi Al-Qur'an Hadis, Akidah Akhlak, Fikih, dan Sejarah Kebudayaan Islam. 
Langkah yang ditempuh oleh MTs. Nurul Ummah dalam mengintegrasikan mata pelajaran PAI di Madrasah dengan mata pelajaran Diniyah di Asrama meliputi tiga hal, yaitu memadatkan waktu menjadi satu, memadukan bahan ajar, dan memadukan metode pembelajaran. Langkah ini merupakan suatu terobosan baru yang tidak ditemukan di sekolah atau madrasah lain. Dengan demikian terobosan ini dapat lebih dikembangkan untuk menghasilkan pendidikan Islam yang komprehensif dan ideal.

\section{DAFTAR PUSTAKA}

Asnawan. "Integrasi Pendidikan Formal dan Pendidikan Diniyah Salafiyah Terhadap Santri Assunniyyah Kencong Jember Sebagai Antisipasi Ouput Pesantren di Era Regulasi Pendidikan." Jurnal Falasifah 7, no. 1 (03 2016).

Direktorat Jendral Kelembagaan Agama Islam Departemen Agama RI. Pondok Pesantren dan Madrasah Diniyah: Pertumbuhan dan Perkembangannya. Jakarta: Departemen Agama RI, 2003.

Echols, John M., dan Hassan Shadily. Kamus Inggris-Indonesia. Jakarta: Gramedia Pustaka Utama, 2007.

Fakhruddin, Udi, Ending Bahrudin, dan Endin Mujahidin. "Konsep Integrasi dalam Sistem Pembelajaran Mata Pelajaran Umum di Pesantren." Ta'dibuna: Jurnal Pendidikan Islam 7, no. 2 (31 Oktober 2018): 214. https://doi.org/10.32832/tadibuna.v7i2.1394.

Fogarty, Robin. Integrate the Curricula. Illinois: IRI/Skylight Publishing, 1991.

Haedani, Amin, dan Hanif Abdullah. Masa Depan Pesantren: Dalam Tantangan Modernitas dan Tantangan Kompleksitas Global. Jakarta: IRD Press, 2004.

Istikomah. "Integrasi Ilmu Sebuah Konsep Pendidikan Islam Ideal." Jurnal Pemikiran Keislaman 28, no. 2 (21 Desember 2017): 408-33. https://doi.org/10.33367/tribakti.v28i2.490.

Kartono, Kartini. Tinjauan Politik Mengenai Sistem Pendidikan Nasional Beberapa Kritik dan Sugesti. Jakarta: Pradnya Paramita, 1997. Kementrian Agama Republik Indonesia. “Keputusan Menteri Agama Republik Indonesia Nomor: 165 Tahun 2014 Tentang Kurikulum 2013 Mata Pelajaran Pendidikan Agama Islam 
dan Bahasa Arab pada Madrasah," 2014. https://jdih.kemenag.go.id/listregulation/detail/5o6aaNE3nJGHgWKHc5uwUA=.

Kountur, Ronny. Metode Penelitian untuk Penulisan Skripsi dan Tesis. Jakarta: PPM, 2004.

Mas'ud, Abdurrahman, Moh Erfan Soebahar, Muhtarom, dan Abdul Mukti. Dinamika Pesantren dan Madrasah. Yogyakarta: Pustaka Pelajar, 2002.

Masyhud, M Sulthon, dan Moh Khusnurdilo. Manajemen Pondok Pesantren. 2 ed. Jakarta: Diva Pustaka, 2005.

Muhaimin. Pengembangan Kurikulum Pendidikan Agama Islam. v ed. Jakarta: Raja Grafindo Persada, 2012.

Munjiat, Siti Maryam. “Integrasi Kurikulum Pesantren Dan Madrasah Pada Pondok Pesantren Manba'ul 'Ulum Sindangmekar Dukupuntang Cirebon." Al-Tarbawi Al-Haditsah: Jurnal Pendidikan Islam 2, no. 2 (2 November 2017). https://doi.org/10.24235/tarbawi.v2i2.2065.

Nasir, Akhmad. Wawancara Kurikulum MTs Nurul Ummah, 2 November 2019.

- - - Wawancara Profil MTs Nurul Ummah, 2 November 2019.

Qomar, Mujamil. Pesantren: Dari Transformasi Metodologi Menuju

Demokratisasi Institusi. Jakarta: Penerbit Erlangga, tt.

Rouf, Muhammad. "Manajemen Kurikulum Integratif MadrasahPesantren (Studi Multisitus di MAN 1 Malang dan Madrasah Terpadu MAN 3 Malang)." Tesis, UIN Maulana Malik Ibrahim Malang, 2016.

Sabda, Syaifuddin. Model Kurikulum Terpadu IPTEK \& IMTAQ. Jakarta: PT. Ciputat Press Group, 2006.

Singorejo, Ibnu. "Jumlah Pondok Pesantren di Indonesia." Diakses 15 Oktober 2019. https://pontren.com/2018/11/20/jumlahpondok-pesantren-di-indonesia/.

Sudjana, Nana, dan Ibrahim. Penelitian dan Penilaian Pendidikan. Bandung: Sinar Baru, 1989.

Sukmadinata, Nana Syaodih, dan Erliana Syaodih. Kurikulum dan Pembelajaran Kompetensi. Bandung: Refika Aditama, 2012.

Syuhada. "Integrasi Sistem Pendidikan Pesantren dan Pendidikan Madrasah: Kasus di Pondok Pesantren DDI Mangkoso Barru." Tesis, UIN Alauddin Makassar, 2016. 
Taulabi, Imam. "Integrasi Sistem Pendidikan Pesantren dan Sekolah." Jurnal Pemikiran Keislaman 24, no. 2 (23 September 2015). https://doi.org/10.33367/tribakti.v24i2.169.

Tim Admisi Nurul Ummah. "Sejarah Singkat Pondok Pesantren Nurul Ummah." Official Website Yayasan Pendidikan Bina Putra. Diakses $20 \quad$ November 2019. https://nurulummah.com/beranda/.

Umam, Ahmad Choirul. Wawancara Profil Asrama Pelajar Nurul Ummah, 1 November 2019.

Wulandari, Ade Putri. "Integrasi Kurikulum Pesantren Dalam Kurikulum 2013 di SMK Al-Munawwir Krapyak Yogyakarta." Jurnal Al-Fahim 2, no. 1 (1 Maret 2020). 